University of Nebraska - Lincoln

DigitalCommons@University of Nebraska - Lincoln

Faculty Papers and Publications in Animal

Science

Animal Science Department

1989

\title{
Influence of Energy and Protein Intake During Lactation on Body Composition of Primiparous Sows
}

\author{
J. H. Brendemuhl \\ University of Florida
}

A. J. Lewis

University of Nebraska-Lincoln, alewis2@unl.edu

E. R. Peo, Jr.

University of Nebraska-Lincoln

Follow this and additional works at: https://digitalcommons.unl.edu/animalscifacpub

Part of the Animal Sciences Commons

Brendemuhl, J. H.; Lewis, A. J.; and Peo, Jr., E. R., "Influence of Energy and Protein Intake During Lactation on Body Composition of Primiparous Sows" (1989). Faculty Papers and Publications in Animal Science. 686.

https://digitalcommons.unl.edu/animalscifacpub/686

This Article is brought to you for free and open access by the Animal Science Department at DigitalCommons@University of Nebraska - Lincoln. It has been accepted for inclusion in Faculty Papers and Publications in Animal Science by an authorized administrator of DigitalCommons@University of Nebraska - Lincoln. 


\title{
INFLUENCE OF ENERGY AND PROTEIN INTAKE DURING LACTATION ON BODY COMPOSITION OF PRIMIPAROUS SOWS 1,2
}

\author{
J. H. Brendemuhl ${ }^{3}$, A. J. Lewis ${ }^{4}$ \\ and E. R. Peo, Jr. \\ University of Nebraska ${ }^{5}$, \\ Lincoln 68583-0908
}

\begin{abstract}
The effects of energy and protein intakes by 32 primiparous sows during a 28 -d lactation on sow and litter performance and sow body composition and bone properties were examined. Dietary treatments were energy intakes of 8 (LE) and 16 (HE) Mcal of $\mathrm{ME} / \mathrm{d}$ and protein intakes of 380 (LP) and 760 (HP) $\mathrm{g}$ of CP/d in a $2 \times 2$ factorial arrangement. Sows fed diets that were inadequate in either energy or protein lost more weight than did sows fed the HE-HP diet, but backfat losses were greater when energy intake was deficient than when protein was deficient. Carcass measurements were influenced in a similar manner, with energy intake affecting $(P<.001)$ backfat thickness and protein intake affecting $(P<.05)$ longissimus muscle area. Heart, kidneys and liver of sows fed LP diets weighed less $(P<.01)$ and contained less water and protein $(P<.05)$ than those of sows fed HP. Sows fed LE had heart, liver and viscera that weighed less $(P$ $<.05)$ than those of sows fed HE. There was less fat $(P<.05)$ in the heart, lung, liver and viscera of sows fed LE than in those of sows fed HE. Carcass components of the supraspinatus muscle and standardized sections through the longissimus muscle and right shoulder weighed less $(P<.05)$ from sows fed LP rather than HP, and these components contained less water and protein. Sows fed the LE diets had less fat in the loin soft tissue section, right shoulder section and supraspinatus muscle than sows fed HE. Bone composition and strength were not influenced by dietary treatment. The composition of weight lost during lactation was diet-dependent. Sows fed diets that were deficient in protein but adequate in energy lost large amounts of protein from muscles and internal organs. Energy deficiency resulted primarily in fat loss.

(Key Words: Sows, Lactation, Body Composition, Energy, Proteins.)
\end{abstract}

J. Anim. Sci. 1989. 67:1478-1488

\section{Introduction}

Restriction of energy and(or) protein intake during lactation results in weight loss and delayed estrus postweaning in primiparous

\footnotetext{
'Published as Paper No. 8708, Journal Series, Nebraska Agric. Res. Div. Research reported was conducted under Project 13-052.

${ }^{2}$ The technical assistance of Mary B. Bames, Ruth $\mathbf{M}$. Diedrichsen, Joy L. Kovar and Roger W. Mandigo is gratefully acknowledged.

${ }^{3}$ Present address: Anim. Sci. Dept., Inst. of Food and Agric. Sci., Univ. of Florida, Gainesville 32611.

4To whom reprint requests should be addressed.

${ }^{5}$ Dept. of Anim. Sci.

Received August 18, 1988.

Accepted November 23, 1988.
}

sows (Reese et al., 1982a,b; King and Williams, 1984; Brendemuhl et al., 1987). Both adipose tissue (O'Grady et al., 1975; Whittemore et al., 1980; Duee and Desmoulin, 1982; Reese et al., 1984) and muscle tissue (O'Grady et al., 1975; Duee and Desmoulin, 1982) may be catabolized during lactation. Thus, the composition of the sow weight loss may be diet-dependent (King and Williams, 1984; King and Dunkin, 1986; Brendemuhl et al., 1987).

Reese et al. (1984), using indirect indices, concluded that loss of body fat was more likely to extend the interval from weaning to first estrus than was muscle tissue catabolism. More recently, Shields et al. (1985), using 
deuterium oxide dilution to estimate body composition, reported that sows fed diets containing 5\% protein during lactation mobilized more maternal tissue than did sows fed higher protein regimens (14 and 23\%). Thus, the relative importance of adipose tissue loss vs muscle tissue loss by sows during lactation on the postweaning estrus interval is unclear. The present research was undertaken to determine the effect of energy and protein intake during lactation on sow body composition at weaning and the relationship between body composition and the postweaning estrus interval.

\section{Experimental Procedure}

Animals and Diets. Thirty-two crossbred primiparous sows (Landrace $\times$ Large White $\times$ Hampshire $\times$ Duroc) were fed $1.8 \mathrm{~kg}$ daily of a diet containing $12 \% \quad \mathrm{CP}$ during gestation (Table 1). Two replications of 16 sows each were farrowed in November 1984 and April 1985, respectively. At parturition, sows were assigned at random within replication to four diets that were fed during a 28-d lactation. Thus, there were eight sows per treatment. Dietary treatments (Table 1) consisted of two energy intakes, 8 (LE) and 16 (HE) Mcal of
$\mathrm{ME} / \mathrm{d}$, and two protein intakes, 380 (LP) and 760 (HP) $\mathrm{g}$ of $\mathrm{CP} / \mathrm{d}$, in a $2 \times 2$ factorial arrangement. All sows received equal daily quantities of vitamins and minerals that met or exceeded National Research Council (NRC, 1979) standards. Sows were given their daily feed allowance in one feeding each morning.

The management of sows during gestation and of sows and pigs during lactation was similar to that described by Brendemuhl et al. (1987), with the following exceptions: 1 ) on $d$ $7,14,21$ and 28 of lactation sows and pigs were weighed and sow backfat thickness was measured; 2) no blood was collected and 3) sows were slaughtered after weaning and thus there were no checks for postweaning estrus.

Body Composition. Before weaning, sows were fasted for $36 \mathrm{~h}$ but were allowed access to water. The sows were transported immediately after weaning to the University of Nebraska Meat Laboratory. They were weighed and slaughtered by conventional USDA-approved procedures. Hot and cold carcass weights were obtained immediately after slaughter and after a $24-\mathrm{h}$ chill at $2^{\circ} \mathrm{C}$, respectively. Carcass measurements were made on the chilled carcass using the methods described by the NPPC (1983). In addition, percentages of lean and fat in the chilled

TABLE 1. COMPOSITION OF GESTATION AND LACTATION DIETS

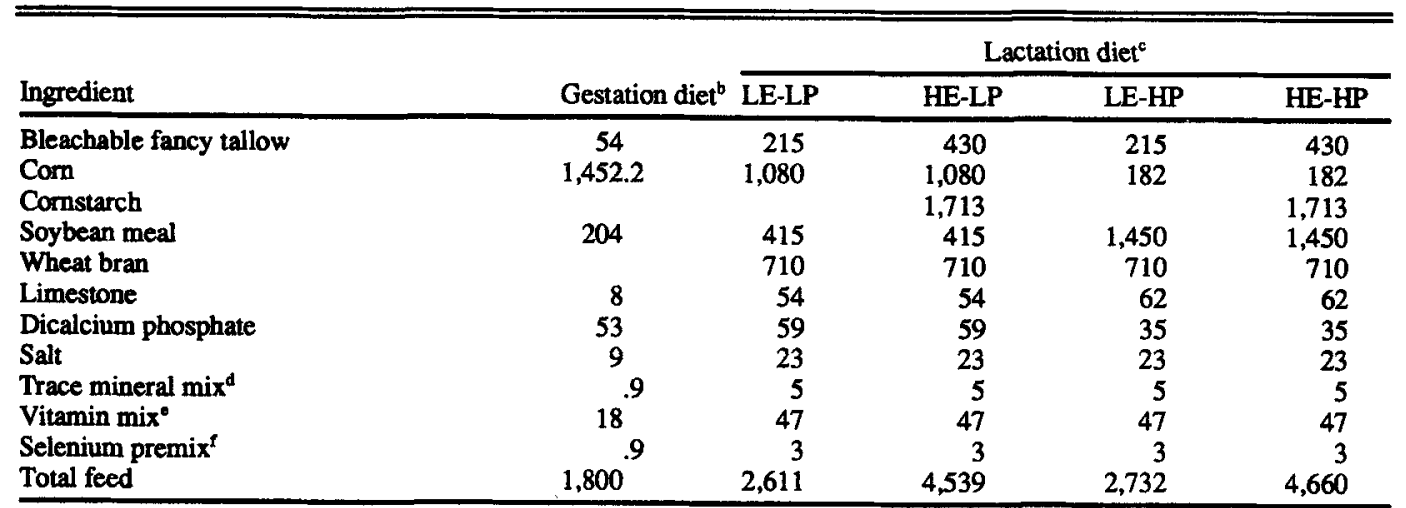

Values represent amounts ( $g / d)$ of each ingredient.

The diet was calculated to provide $5.8 \mathrm{Mcal} \mathrm{ME} / \mathrm{d}, 216 \mathrm{~g}$ protein/d, $16.2 \mathrm{~g} / \mathrm{d}$ of $\mathrm{Ca}$ and $14.6 \mathrm{~g} / \mathrm{d}$ of $\mathrm{P}$.

'LE = low energy (8 Mcal ME/d); LP = low protein ( $380 \mathrm{~g} \mathrm{CP} / \mathrm{d}) ; \mathrm{HE}=$ high energy (16 Mcal ME/d); HP = high protein $(760 \mathrm{~g} \mathrm{CP} / \mathrm{d})$. All diets were calculated to provide $35.5 \mathrm{~g} / \mathrm{d}$ of $\mathrm{Ca}$ and $24.8 \mathrm{~g} / \mathrm{d}$ of $\mathrm{P}$.

dComposition (\%): $\mathrm{Zn}, 20 ; \mathrm{Fe}, 10 ; \mathrm{Mn}, 5.5 ; \mathrm{Cu}, 1.1 ; 1, .15$.

'Composition per kg of premix: vitamin A (stabilized), 551,146 IU; vitamin $\mathrm{D}_{3}$ (stabilized), 55,115 IU; riboflavin, 551 $\mathrm{mg}$; d-pantothenic acid, 1,984 mg; niacin, $3,307 \mathrm{mg}$; choline chloride, $55,115 \mathrm{mg}$; vitamin $B_{12}, 1.65 \mathrm{mg}$; menadione sodium bisulfite, $220 \mathrm{mg}$; ethoxyquin, $.44 \mathrm{~g}$; vitamin E, 2,205 IU.

${ }^{8}$ Composition (\%): Se, .02. 
carcass were estimated by obtaining a core of tissue between the 10th and 11th ribs as described by Lu et al. (1958).

The body components of each sow were divided into seven composites, weighed (wet weight) and identified as follows: 1) heart, with blood clots removed and veins and arteries excised from the dorsal portion; 2) kidneys; 3) lungs, with trachea removed 2.5 $\mathrm{cm}$ anterior to the bifurcation of the two main bronchi; 4) spleen; 5) liver, with gall bladder removed; 6) viscera, which included (after removal of gut contents) the esophagus, stomach, small and large intestines, cecum, pancreas, mesentery tissue, reproductive tract, urinary bladder, trachea, gall bladder and leaf fat, and 7) carcass. In addition, mammary tissue was obtained by removing an area approximately $8 \mathrm{~cm}$ peripherally and parallel to the teat lines; it was weighed and discarded. The first six composites were placed in separate plastic bags, sealed and stored at $-20^{\circ} \mathrm{C}$ until they were ground for chemical analysis.

The seventh composite (carcass) was divided into three further components as follows: $7 \mathrm{~A}$ ) right shoulder, which consisted of a 5-cm section cut through the entire right half of the carcass beginning at the anterior edge of the first rib and proceeding posteriorly; 7B) loin, which consisted of a $5-\mathrm{cm}$ section cut through the entire right half of the carcass beginning at the anterior edge of the 10th rib and proceeding posteriorly; this section was then cut 2.5 $\mathrm{cm}$ below the base of the longissimus muscle to remove the ribs, and 7C) left supraspinanus muscle, which consisted of the entire muscle removed from its point of origin on the supraspinous fossa to its insertion on the major tuberosity of the humerus. Right shoulder (7A) and loin (7B) were deboned and the loin component was separated further by isolating the longissimus muscle (7B1) from remaining loin soft tissue (7B2). All components of the carcass composite were weighed, sealed in plastic bags and stored at $-20^{\circ} \mathrm{C}$ until they were ground for chemical analysis.

Frozen samples were ground through a meat grinder ${ }^{6}$ with a $6.4-\mathrm{mm}$ plate. The sample obtained from the first grind was mixed thoroughly and then ground twice through a 3-mm plate. Samples were mixed thoroughly,

${ }^{6} \mathrm{Hobart}$, Troy, $\mathrm{OH}$.

${ }^{7}$ Model TM 1123, Instron Corp., Canton, MA. subsampled, sealed in plastic bags and stored at $-20^{\circ} \mathrm{C}$ until analyzed. All samples were analyzed for DM, N, crude fat and ash using methods described by the AOAC (1980).

Bone Collection and Analysis. The left rear foot was collected from each sow at slaughter and stored at $-20^{\circ} \mathrm{C}$. After thawing at room temperature, the third and fourth metatarsals were excised from the surrounding soft tissue. The bones were sealed in plastic bags and stored at $-20^{\circ} \mathrm{C}$. The strength of the bones was determined by thawing them at room temperature and subjecting them to physical measurements with an Instron Universal Testing Machine ${ }^{7}$. The bones then were soaked in methanol for $24 \mathrm{~h}$, extracted with anhydrous ethyl ether and dried at $105^{\circ} \mathrm{C}$. After drying, bones were weighed, and inside and outside diameters were measured. Bones then were ashed at $700^{\circ} \mathrm{C}$ for $24 \mathrm{~h}$. Concentrations of $\mathrm{Ca}$ and $\mathrm{P}$ in the bone ash were determined by the automated procedures described by Frankel et al. (1970). Maximum stress and cortical bone thickness were calculated for each bone using methods developed by Crenshaw et al. (1981). Average of values for the third and fourth metatarsals were used in the statistical analyses of bone data.

Statistical Analysis. The effects of energy and protein intakes and their interaction on the various response criteria were analyzed using least squares analysis of covariance (SAS, 1979; Steel and Torrie, 1980) with sow as the experimental unit. Average backfat thickness on d 110 of gestation, post-farrowing weight and litter size on $\mathrm{d} 3$ postpartum were used as covariates to remove the portion of the variation that was associated with these traits. The average values of these covariates were: backfat thickness, 31.9, 34.7, 30.3 and 30.3 $\mathrm{mm}$; post-farrowing weight, 167.8, 174.4, 173.1 and $164.3 \mathrm{~kg}$; litter size, 10.1, 9.9, 10.0 and 10.5 for diets LE-LP, HE-LP, LE-HP and HE-HP, respectively. Litter size 3 d postpartum was the only covariate used in the analysis of pig performance. Simple correlations were determined according to the methods described by SAS (1979) and Steel and Torrie (1980).

\section{Results and Discussion}

Sow and Litter Performance. The effects of energy and protein intakes by primiparous sows during lactation on the weekly weight and backfat changes of sows are presented in 
Table 2. During the 1st wk of lactation, weight loss of sows fed diets containing LP was greater $(P<.07)$ than that of sows fed diets with HP. During the 2nd wk of lactation sows fed diets with LE and LP had greater weight losses $(P<.01)$ than sows fed HE or HP. Weight losses during the 2nd wk of lactation were less than losses during the 1st wk for each dietary treatment. Sows fed diets with LE $(P<.08)$ or LP $(P<.05)$ lost more weight during the 3rd wk of lactation than sows fed diets with HE or HP. The greatest weight loss occurred during the 4 th wk of lactation for all treatments, but there were no energy or protein effects $(P>.20)$. No energy $\times$ protein interactions $(P>.10)$ were observed for sow weight change during any of the 4 wk of lactation. The greater weight loss during the 4th wk of lactation may have been caused by increased milk production, because sows reach peak milk production between the 3rd and 5th wk of lactation (Allen and Lasley, 1960).

During the 1st wk of lactation, backfat loss was not affected by energy intake $(P>.16)$, but sows fed diets with HP lost more backfat $(P<.08)$ than sows fed diets containing LP.
During the 2nd and 3rd wk of lactation, protein did not influence backfat loss, but sows consuming diets with LE had greater losses during the 2 nd $(P<.01)$ and 3 rd wk $(P=.07)$ than sows fed diets with $\mathrm{HE}$. Backfat losses during the 4th wk of lactation were affected by both LE $(P<.01)$ and HP $(P<.04)$; sows fed either treatment lost more backfat than sows fed diets containing HE or LP. No energy $x$ protein interactions $(P>.50)$ were observed at any week during lactation. The changes in backfat thickness were similar to those reported previously by Brendemuhl et al. (1987).

The effects of sow energy and protein intake on pig performance are also presented in Table 2. At weaning (d 28), sows fed diets with HE had heavier $(P<.02)$ pigs than sows fed diets containing LE. Protein intake had no effect on pig weight on d 28 of lactation. Litter weight was not affected by either protein or energy intake. Litter size at weaning was smaller $(P<.03)$ for sows fed diets with $\mathrm{HE}$ than for sows fed diets with LE.

Pig performance in the present experiment was not consistent with an earlier experiment (Brendemuhl et al., 1987). In the previous

TABLE 2. EFFECT OF ENERGY AND PROTEIN INTAKE BY PRIMIPAROUS SOWS DURING LACTATION ON SOW AND PIG PERFORMANCE"

\begin{tabular}{|c|c|c|c|c|c|}
\hline \multirow[b]{2}{*}{ Item } & \multicolumn{4}{|c|}{ Lactation diet ${ }^{b}$} & \multirow[b]{2}{*}{$\mathrm{CV}$} \\
\hline & LE-LP & HE-LP & LE-HP & HE-HP & \\
\hline $\begin{array}{l}\text { Lactation wt change } \\
0 \text { to } 7 \mathrm{~d} \\
7 \text { to } 14 \mathrm{~d} \\
14 \text { to } 21 \mathrm{~d} \\
21 \text { to } 28 \mathrm{~d}\end{array}$ & $\begin{array}{r}-8.6 \\
-7.6 \\
-7.3 \\
-11.7\end{array}$ & $\begin{array}{r}-9.1 \\
-5.4 \\
-6.7 \\
-10.6\end{array}$ & $\begin{array}{r}-7.4 \\
-6.1 \\
-6.2 \\
-10.2\end{array}$ & $\begin{array}{r}-3.3 \\
-.6 \\
-2.1 \\
-5.5\end{array}$ & $\begin{array}{l}65.8^{\mathrm{c}} \\
52.6^{\text {de }} \\
63.0^{\text {fo }} \\
58.6^{2}\end{array}$ \\
\hline $\begin{array}{l}\text { Lactation backfat ch } \\
0 \text { to } 7 \mathrm{~d} \\
7 \text { to } 14 \mathrm{~d} \\
14 \text { to } 21 \mathrm{~d} \\
21 \text { to } 28 \mathrm{~d} \\
\text { Pig wt (d 28), kg } \\
\text { Litter wt (d 28), kg } \\
\text { Litter size (d 28) }\end{array}$ & $\begin{array}{r}-2.1 \\
-2.1 \\
-2.1 \\
-2.7 \\
5.9 \\
57.3 \\
9.9\end{array}$ & $\begin{array}{c}-.3 \\
-.1 \\
-2.7 \\
0 \\
6.2 \\
59.0 \\
9.7\end{array}$ & $\begin{array}{r}-4.5 \\
-2.4 \\
-1.5 \\
-3.8 \\
5.7 \\
55.0 \\
10.0\end{array}$ & $\begin{array}{r}-2.6 \\
-.7 \\
-2.2 \\
-1.8 \\
6.7 \\
57.1 \\
8.6\end{array}$ & $\begin{array}{c}77.7^{\mathrm{c}} \\
94.5^{\mathrm{d}} \\
80.3^{\mathrm{t}} \\
70.2^{\mathrm{d}} \\
8.6^{\mathrm{b}} \\
14.1 \\
9.6^{\mathrm{h}}\end{array}$ \\
\hline
\end{tabular}

-Values are least squares means (eight sows per dietary treatment).

'LE = low energy (8 Mcal ME/d); LP = low protein ( $380 \mathrm{~g} \mathrm{CP/d}) ; \mathrm{HE}=$ high energy (16 Mcal ME/d); HP = high protein $(760 \mathrm{~g} \mathrm{CP} / \mathrm{d})$.

Protein effect $(P<.10)$.

Energy effect $(P<.01)$.

Protein effect $(P<.01)$.

Energy effect $(P<.10)$.

Protein effect $(P<.05)$.

'Energy effect $(P<.05)$. 
experiment, both energy and protein affected pig weight; sows fed diets with HE or HP produced heavier pigs, and sows fed diets containing HP had heavier litters than sows fed diets with LP. Also in the previous experiment, litter size was smaller in sows fed HP than in those fed LP. The differences between experiments probably are associated with the relatively small number of observations (32) in the present research compared with a larger number of observations (221) in the previous experiment.

Sow Carcass Measurements. Live weight at slaughter was greater for sows fed diets containing HP $(P<.08)$, whereas energy had no effect on live weight at slaughter (Table 3 ). Hot carcass weight was greater $(P<.01)$ for sows fed HE and HP than for sows fed LE or LP diets. Similar responses were observed for cold carcass weight. Dressing percentage and carcass length were similar among treatments. Tenth rib fat and average backfat thickness were greater in sows fed HE $(P<.001)$ than in sows fed LE. Protein did not influence 10th rib fat or average backfat, but sows fed diets containing $\mathrm{HP}$ had larger $(P<.03)$ longissimus muscle areas than sows fed LP. No energy $x$ protein interactions $(P>.10)$ were observed for any of the carcass measurements.

The effects of diet on weight at slaughter and carcass backfat measurements are consistent with the measurements taken during lactation. Sow weight was influenced more by protein intake than energy intake, whereas backfat thickness was influenced more by energy intake than by protein intake.

Carcass Fat and Lean Percentage. Estimates of carcass fat and lean of sows at weaning were made by obtaining a core sample between the 10th and 11 th ribs as described by Lu et al. (1958). Results are shown in Table 4. The estimate of carcass fat was greater in sows fed HE $(P<.03)$ than in sows fed LE and was greater in sows fed LP $(P<.05)$ than in sows fed HP. No energy $x$ protein interactions $(P>.10)$ were observed. Carcass lean was affected by energy $(P<.05)$ and protein $(P<.06)$ intakes of sows; sows fed LE had a higher percentage of carcass lean than sows fed HE, whereas sows fed HP had greater carcass lean than sows fed LP.

Simple correlations (Table 5) of carcass fat with average backfat thickness, 10 th rib fat thickness, heart fat, liver fat, longissimus muscle fat and supraspinatus muscle fat were significant $(P<.05)$. Correlations of carcass

TABLE 3. EFFECT OF ENERGY AND PROTEIN INTAKE BY PRIMIPAROUS SOWS DURING LACTATION ON SOW CARCASS MEASUREMENTS"

\begin{tabular}{|c|c|c|c|c|c|}
\hline \multirow[b]{2}{*}{ litem } & \multicolumn{4}{|c|}{ Lactation diet } & \multirow[b]{2}{*}{$\mathrm{CV}$} \\
\hline & LE-LP & HE-LP & LE-HP & HE-HP & \\
\hline $\begin{array}{l}\text { Live wt, } \mathrm{kg} \\
\text { Hot carcass wh, kg } \\
\text { Cold carcass wt, } \mathrm{kg} \\
\text { Dressing percentage } \\
\text { Carcass length, cm } \\
\text { 10th Rib fat thickness, mm } \\
\text { Backfat thickness', mm } \\
\text { Longissimus muscle area, } \mathrm{cm}^{2}\end{array}$ & $\begin{array}{r}134.7 \\
92.6 \\
90.6 \\
69.6 \\
94.7 \\
31.4 \\
33.8 \\
32.5\end{array}$ & $\begin{array}{r}134.3 \\
96.1 \\
94.1 \\
70.3 \\
94.3 \\
37.8 \\
38.3 \\
28.7\end{array}$ & $\begin{array}{r}135.7 \\
96.1 \\
94.2 \\
69.2 \\
94.5 \\
28.5 \\
31.6 \\
34.0\end{array}$ & $\begin{array}{r}150.4 \\
108.0 \\
105.9 \\
70.1 \\
96.8 \\
35.6 \\
40.1 \\
34.5\end{array}$ & $\begin{array}{r}8.6^{\mathrm{e}} \\
6.5^{\mathrm{e}} \\
6.6^{\mathrm{e}} \\
2.4 \\
2.7 \\
12.6^{\mathrm{e}} \\
13.2^{\mathrm{e}} \\
11.3^{\mathrm{i}}\end{array}$ \\
\hline
\end{tabular}

"Values are least squares means (eight sows per dietary treatment).

乙E = low energy $(8 \mathrm{Mcal} \mathrm{ME} / \mathrm{d}) ; \mathrm{LP}=$ low protein $(380 \mathrm{~g} \mathrm{CP} / \mathrm{d}) ; \mathrm{HE}=$ high energy $(16 \mathrm{Mcal} \mathrm{ME} / \mathrm{d}) ; \mathrm{HP}=$ high protein $(760 \mathrm{~g} C P / \mathrm{d})$.

'Recorded immediately before slaughter.

Protein effect $(P<.10)$.

Energy effect $(P<.01)$.

Procein effect $(P<.01)$.

Recorded after a $24-\mathrm{h}$ chill at $2^{\circ} \mathrm{C}$.

r(Cold carcass whlive $w t) \times 100$.

'Average of first rib, last rib and lumbar vertebra.

Protein effect $(P<.05)$. 
lean with longissimus muscle cross-section area, heart protein, liver protein, spleen protein, longissimus muscle protein and supraspinatus muscle protein were not different from zero $(P>.40)$. The data indicate that the method of Lu et al. (1958) may be inaccurate for estimating carcass lean in sows. Thus, the equations developed from data obtained with growing-finishing pigs may not be appropriate for predicting carcass fat and lean of sows.

Sow Internal Organs. Heart weights were heavier $(P<.02)$ in sows fed diets with HE and HP than in sows fed diets containing LE or LP (Table 6). Sows fed diets containing HE or HP had more water and protein in heart tissue than did sows fed either diets with LE or LP content. Protein did not affect the fat or ash component of the heart, but these components were influenced by energy intake. There was an energy $\times$ protein interaction $(P<.07)$ for the ash content; ash content increased in response to energy to a greater extent when protein intake was high.

Kidney weights and compositions were not affected by dietary energy level. However, sows fed diets with HP had heavier kidneys $(P$ $<.001)$ that contained more water, protein and ash $(P<.001)$ than did sows fed diets with LP. Fat content was unaffected by dietary protein intake, but an energy $\times$ protein interaction $(P$ $<.03$ ) was observed for kidney fat. As energy level increased for sows fed the diet with LP, there was a decrease in kidney fat, whereas the opposite effect occurred when energy level increased for sows fed the diet with HP. Similar energy $x$ protein interactions were present for kidney weight $(P<.04)$, protein $(P=.06)$ and ash $(P<.02)$ contents.

Lung weights and compositions were not different among treatments, except for fat. Sows fed diets containing HE had more lung fat $(P<.06)$ than sows fed diets with LE. Energy and protein intakes did not influence spleen weights or compositions. Furthermore, no energy $\times$ protein interactions were observed for either the lungs or the spleen.

Energy and protein intakes had profound effects on the weight of the liver and its composition. Sows fed diets with HE or HP had heavier livers $(P<.01$ and $<.001$, respectively) than did sows consuming diets with LE or LP. In addition, livers of sows fed diets with HE or HP had more water, fat and ash. Protein content of the liver was unaffected by energy intake, but livers of sows fed diets with HP contained more protein $(P<.001)$ than livers of sows consuming LP diets. Energy $\times$ protein interactions $(P<.05)$ were observed for liver weight, water, protein and ash. The interactions observed for the liver components were similar to those for the kidney.

Viscera weights were heavier $(P<.04)$ in sows fed diets containing $\mathrm{HE}$ than in those fed LE; protein had no effect. However, protein effects were observed in viscera protein $(P<$ .03 ), which was increased in sows fed diets with HP compared with those fed LP. Further-

TABLE 4. EFFECT OF ENERGY AND PROTEIN INTAKE BY PRIMIPAROUS SOWS DURING LACTATION ON ESTIMATES OF THE PERCENTAGE CARCASS FAT AND LEAN ${ }^{b}$

\begin{tabular}{|c|c|c|c|c|c|}
\hline \multirow[b]{2}{*}{ Item } & \multicolumn{4}{|c|}{ Lactation diet ${ }^{b}$} & \multirow[b]{2}{*}{ CV } \\
\hline & LE-LP & HE-LP & LE-HP & HE-HP & \\
\hline \multicolumn{6}{|c|}{ Carcass fat, $\%$} \\
\hline Left side & 38.0 & 42.2 & 38.0 & 39.0 & $8.6^{c}$ \\
\hline Right side & 38.3 & 41.7 & 36.8 & 37.5 & $8.9^{d}$ \\
\hline Mean & 38.1 & 42.0 & 37.4 & 38.3 & $6.9^{\mathrm{ed}}$ \\
\hline \multicolumn{6}{|c|}{ Carcass lean, \% } \\
\hline Left side & 45.6 & 42.2 & 45.3 & 45.0 & 7.0 \\
\hline Right side & 45.5 & 42.8 & 46.6 & 46.1 & $6.9^{d}$ \\
\hline Mean & 45.6 & 42.5 & 46.0 & 45.5 & $5.0^{\infty}$ \\
\hline
\end{tabular}

"Percentage carcass fat and lean were estimated using the method of Lu et al. (1958).

${ }^{b}$ Values are least squares means (eight sows per dietary treatment). LE = low energy $(8 \mathrm{Mcal} \mathrm{ME} / \mathrm{d}$ ); L.P = low protein ( $380 \mathrm{~g} \mathrm{CP} / \mathrm{d}) ; \mathrm{HE}=$ high energy $(16 \mathrm{Mcal} \mathrm{ME} / \mathrm{d}) ; \mathrm{HP}=$ high protein $(760 \mathrm{~g} \mathrm{CP} / \mathrm{d})$.

Energy effect $(P<.05)$.

'Protein effect $(P<.05)$.

Protein effect $(P<.10)$. 
more, sows consuming the HE diet had more fat in their viscera than did sows consuming diets with LE. Energy $\times$ protein interactions were observed for viscera water $(P<.06)$ and protein $(P<.01)$.

The data indicate that internal organs undergo substantial catabolism to provide energy (fat) and(or) protein for metabolic functions when dietary intake is inadequate to meet demands. Heart and liver weights of sows fed diets containing LE or LP were lower than those of sows fed HE or HP. Kidney weights were lower in sows fed diets containing LP than in those fed HP, whereas the viscera weighed less in sows fed diets containing LE than in those fed HE. Elsley et al. (1968) reported that liver, heart, lung, kidney and spleen weights were lower in sows that consumed diets restricted in energy during gestation for four parities. Lung and spleen weights were unaffected in our experiment.

The losses of organ weight and amounts of water, protein, fat and ash from sows fed diets restricted in energy and(or) protein indicate that sows mobilize body reserves from internal organs to nourish their litters. This conclusion is in agreement with data reported by Elsley et al. (1968) and Shields et al. (1985), who described maternal tissue mobilization under nutrient deprivation to fulfill reproductive needs. Furthermore, we have reported previously (Brendemuhl et al., 1987) that the dietary regimens used in the present research influence return to estrus of primiparous sows after weaning. Thus, reproductive functions also may be suppressed to conserve substrates for nourishment of the litter.

The energy $\times$ protein interactions observed were similar for organ weights and their components. Decreases in weight were observed when energy was increased in the LP diet. A possible explanation is that protein was the first limiting nutrient in the diet of sows fed LE-LP and the addition of energy created a dietary imbalance that further accentuated the metabolic demands for protein and increased

TABLE 5. SIMPLE CORRELATION COEFFICIENTS OF ESTIMATED PERCENTAGE CARCASS FAT AND LEAN WITH CARCASS MEASUREMENTS AND ORGAN COMPOSITIONS

\begin{tabular}{|c|c|c|}
\hline Item & Carcass fat ${ }^{\mathbf{2}}$ & Carcass lean" \\
\hline $\begin{array}{l}\text { Backfat thickness } \\
\text { 10th Rib fat thickness }\end{array}$ & $\begin{array}{l}.765^{* * * *} \\
.870^{* * *}\end{array}$ & \\
\hline Longissimus muscle area & & .116 \\
\hline Heart & & \\
\hline $\begin{array}{l}\text { Fat }^{c} \\
\text { Protein }^{d}\end{array}$ & $.355^{*}$ & .150 \\
\hline Liver & & \\
\hline $\begin{array}{l}\text { Fat }^{\mathrm{c}} \\
\text { Protein }^{\mathrm{s}}\end{array}$ & $.488^{* *}$ & .018 \\
\hline Spleen & & \\
\hline $\begin{array}{l}\text { Fat } \\
\text { Protein }\end{array}$ & .083 & .148 \\
\hline Longissimus muscle ${ }^{\circ}$ & & \\
\hline $\begin{array}{l}\text { Fat }^{\mathrm{c}} \\
\text { Protein }^{\mathrm{d}}\end{array}$ & $.759 * * *$ & .015 \\
\hline $\begin{array}{l}\text { Supraspinatus muscle } \\
\text { Fat }^{f} \\
\text { Protein }^{d}\end{array}$ & $.638 * * *$ & -.011 \\
\hline
\end{tabular}

"Percentage carcass fat and lean were estimated by the methods of Lu et al. (1958).

'Average of first rib, last rib and last lumbar vertebra.

Represents the total weight $(\mathrm{g})$ of fat in the component.

Represents the total weight ( $g$ ) of protein in the component.

Represents the longissimus muscle that was removed from a $5-\mathrm{cm}$ section cut from the right side beginning at the anterior edge of the 10th rib and proceeding posteriorly.

Represents the entire muscle removed from the left shoulder.

$* P<.05$.

$* * P<.01$.

$* * * P<.001$. 
TABLE 6. EFFECT OF ENERGY AND PROTEIN INTAKE BY PRIMIPAROUS SOWS DURING LACTATION ON THE WEIGHT AND COMPOSITION OF THEIR INTERNAL ORGANS"

\begin{tabular}{|c|c|c|c|c|c|}
\hline \multirow[b]{2}{*}{ Item } & \multicolumn{4}{|c|}{ Lactation diet ${ }^{b}$} & \multirow[b]{2}{*}{$\mathrm{CV}$} \\
\hline & LE-LP & HE-LP & LE-HP & HE-HP & \\
\hline \multicolumn{6}{|l|}{ Heart, $\mathrm{g}$} \\
\hline Wet $w^{e}$ & 403.5 & 428.9 & 428.1 & 492.8 & $10.2^{\text {de }}$ \\
\hline Water & 307.4 & 323.0 & 329.8 & 372.5 & $10.0^{\text {de }}$ \\
\hline Protein & 66.7 & 69.0 & 70.1 & 82.1 & $11.6^{\text {de }}$ \\
\hline Fat & 26.0 & 33.2 & 25.6 & 32.4 & $18.5^{t}$ \\
\hline Ash & .97 & 1.01 & .90 & 1.20 & $16.8^{t}$ \\
\hline \multicolumn{6}{|l|}{ Kidney, 8} \\
\hline Wet $w t^{c}$ & 365.8 & 335.3 & 388.4 & 422.6 & $9.5^{8}$ \\
\hline Water & 277.3 & 262.8 & 301.4 & 325.3 & $9.8^{8}$ \\
\hline Protein & 47.0 & 43.1 & 51.2 & 55.5 & $10.6^{8}$ \\
\hline Fat & 36.4 & 25.4 & 30.1 & 35.2 & 26.0 \\
\hline Ash & .90 & .70 & .95 & 1.00 & 13.7 \\
\hline \multicolumn{6}{|l|}{ Lung, $g$} \\
\hline Wet wte & $1,014.9$ & $1,159.9$ & $1,004.5$ & $1,134.3$ & 20.5 \\
\hline Water & 873.7 & $1,006.8$ & 864.6 & 975.6 & 22.6 \\
\hline Protein & 106.2 & 109.2 & 104.1 & 115.3 & 12.3 \\
\hline Fal & 28.4 & 36.1 & 31.4 & 35.9 & $25.1^{h}$ \\
\hline Ash & .99 & .94 & 1.00 & 1.11 & 21.2 \\
\hline \multicolumn{6}{|l|}{ Spleen, $\mathbf{g}$} \\
\hline Wet wtc & 175.1 & 176.4 & 192.1 & 218.7 & 26.8 \\
\hline Water & 134.5 & 135.3 & 148.5 & 168.5 & 26.6 \\
\hline Protein & 29.7 & 30.3 & 33.4 & 37.7 & 30.6 \\
\hline Fat & 7.6 & 7.4 & 7.3 & 9.3 & 32.2 \\
\hline Ash & .59 & .60 & .60 & .67 & 24.7 \\
\hline \multicolumn{6}{|l|}{ Liver, $\mathbf{g}$} \\
\hline Wet wte & $1,773.5$ & $1,763.6$ & $1,863.7$ & $2,286.1$ & $10.2^{28}$ \\
\hline Water & $1,224.0$ & $1,210.6$ & $1,323.7$ & $1,601.9$ & $10.4^{d x}$ \\
\hline Protein & 325.4 & 308.0 & 381.0 & 434.3 & $10.4^{*}$ \\
\hline Fat & 187.7 & 205.3 & 105.6 & 190.0 & $34.4^{\text {de }}$ \\
\hline Ash & 7.4 & 7.3 & 7.4 & 9.4 & $14.3^{\text {de }}$ \\
\hline \multicolumn{6}{|l|}{ Viscera, $\mathbf{g}$} \\
\hline Wet $w t^{c}$ & $12,326.7$ & $12,642.0$ & $11,394.4$ & $13,209.6$ & $10.7^{d}$ \\
\hline Water & $7,641.6$ & $6,870.4$ & $7,082.1$ & 7.798 .8 & 12.7 \\
\hline Protein & $1,101.3$ & 911.1 & $1,061.6$ & $1,187.8$ & $11.7^{\circ}$ \\
\hline Fat & $3,177.1$ & $4,419.9$ & $2,897.5$ & $3,800.6$ & $18.7^{f j}$ \\
\hline Ash & 58.4 & 59.7 & 54.7 & 62.7 & 17.4 \\
\hline
\end{tabular}

"Values are least squares means (eight sows per dietary treatment).

'LE = low energy (8 Mcal ME/d); LP = low protein (380 g CP/d); HE = high energy (16 Mcal ME/d); HP = high protein (760 g CP/d).

Weight of organ immediately after slaughter.

'Energy effect $(P<.05)$.

Protein effect $(P<.05)$.

Energy effect $(P<.01)$.

Protein effect $(P<.01)$.

'Energy effect $(P<.10)$.

includes the esophagus, stomach, small and large intestine, cecum, pancreas, mesentery tissue, bladder, reproductive tract, trachea, gall bladder and leaf fat.

Protein effect $(P<.10)$.

mobilization of protein and fat from the organs. The opposite effect occurred when energy was added to the high-protein diet because energy was the primary limitation in the LE-HP diet.
Sow Carcass Composition. There were no effects of energy on the weight or the amount of water, protein, fat and ash of the longissimus muscle section (Table 7). Weight of the longissimus muscle section and its protein, 
water and ash contents were greater $(P<.01)$ in sows fed diets containing HP than in sows fed LP diets. Significant $(P<.10)$ energy $\times$ protein interactions for longissimus muscle section weight and for water, protein and ash content also were observed. The interactions were similar to those described for the internal organs.

The soft tissue component from the loin section was heavier $(P<.01)$ in sows fed diets containing HE than in those fed LE. The fat content was much greater $(P<.01)$ in sows fed $\mathrm{HE}$ than in sows fed LE and was primarily responsible for the difference in loin soft tissue weight. Water $(P<.01)$, protein $(P<.01)$ and ash $(P<.02)$ contents of the loin soft tissue were greater in sows fed HP than in those fed LP. There were no significant energy $\times$ protein interactions for the loin soft tissue.

Right shoulder sections were heavier $(P<$ $.06)$ and contained more water and protein ( $P$ $<.01$ ) in sows fed diets containing $\mathrm{HP}$ than in

TABLE 7. EFFECT OF ENERGY AND PROTEIN INTAKE BY PRIMIPAROUS SOWS DURING LACTATION ON THE WEIGHT AND COMPOSITION OF THEIR VARIOUS CARCASS COMPONENTS ${ }^{2}$

\begin{tabular}{|c|c|c|c|c|c|}
\hline \multirow[b]{2}{*}{ Item } & \multicolumn{4}{|c|}{ Lactation $\operatorname{diet}^{b}$} & \multirow[b]{2}{*}{$\mathrm{CV}$} \\
\hline & LE-LP & HE-LP & LE-HP & HE-HP & \\
\hline \multicolumn{6}{|c|}{ Longissimus musclec, g } \\
\hline Wet wt & 188.7 & 165.7 & 199.2 & 209.0 & $11.8^{\mathrm{e}}$ \\
\hline Water & 141.4 & 123.6 & 147.6 & 154.2 & $11.7^{\mathrm{e}}$ \\
\hline Protein & 40.2 & 34.2 & 43.8 & 45.4 & $12.7^{\mathrm{e}}$ \\
\hline Fat & 5.6 & 6.8 & 5.9 & 6.9 & 33.3 \\
\hline Ash & .48 & .42 & .54 & .61 & $13.6^{e}$ \\
\hline \multicolumn{6}{|c|}{ Loin soft tissue, $\mathrm{g}$} \\
\hline Wet $w t^{d}$ & 258.3 & 295.8 & 270.6 & 348.8 & $17.6^{8}$ \\
\hline Water & 68.3 & 71.9 & 83.8 & 85.3 & $16.1^{e}$ \\
\hline Protein & 18.0 & 18.1 & 23.4 & 22.8 & $19.1^{\mathrm{e}}$ \\
\hline Fat & 172.6 & 205.8 & 166.1 & 241.1 & $23.0^{2}$ \\
\hline Ash & .64 & .70 & .82 & 86 & $20.8^{\text {h }}$ \\
\hline \multicolumn{6}{|c|}{ Right shoulder', g } \\
\hline Wet $w t^{t}$ & $2,357.7$ & $2,465.7$ & $2,633.9$ & $2,834.1$ & 15.6 \\
\hline Water & $1,401.8$ & $1,309.6$ & $1,618.5$ & $1,597.3$ & $15.1^{\circ}$ \\
\hline Protein & 362.9 & 346.4 & 430.7 & 426.7 & $15.5^{\circ}$ \\
\hline Fat & 573.8 & 811.9 & 583.9 & 813.7 & $25.7^{8}$ \\
\hline Ash & 7.4 & 7.8 & 8.0 & 9.1 & 17.3 \\
\hline \multicolumn{6}{|c|}{ Supraspinatus muscle $e^{k}, g$} \\
\hline Wet $w t^{d}$ & 538.7 & 498.9 & 575.6 & 581.6 & $9.9^{\circ}$ \\
\hline Water & 406.7 & 375.0 & 435.1 & 432.5 & $10.7^{\mathrm{h}}$ \\
\hline Protein & 99.3 & 89.8 & 111.6 & 110.7 & $11.5^{\circ}$ \\
\hline Fat & 29.3 & 31.5 & 26.2 & 37.0 & $20.7^{1}$ \\
\hline Ash & 1.30 & 1.24 & 1.48 & 1.48 & $10.2^{\mathrm{e}}$ \\
\hline
\end{tabular}

-Values are least squares means (eight sows per dietary treatment).

'LE = low energy (8 Mcal ME/d); LP = low protein $(380 \mathrm{~g} \mathrm{CP} / \mathrm{d}) ; \mathrm{HE}=$ high energy $(16 \mathrm{Mcal} \mathrm{ME} / \mathrm{d}) ; \mathrm{HP}=$ high protein ( $760 \mathrm{~g} \mathrm{CP} / \mathrm{d}$ ).

'Represents the longissimus muscle that was removed from a 5-cm section cut from the right side beginning at the anterior edge of the 10th rib and proceeding posteriorly.

"Weight of carcass components immediately after slaughter.

Protein effect $(P<.01)$.

Represents the soft tissue remaining after the longissimus muscle was removed (see footnote $c$ ).

Energy effect $(P<.01)$.

"Protein effect $(P<.05)$.

'Represents a 5-cm section cut through the right shoulder beginning at the anterior edge of the first rib and proceeding posteriorly.

JProtein effect $(P<.10)$.

Represents the entire muscle removed from the left shoulder.

'Energy effect $(P<.05)$. 
those fed LP. Energy intake affected only the fat content, with an increased fat content $(P$ $<.01$ ) in sections of sows fed HE compared with sows fed LE diets. There were no energy $x$ protein interactions.

The left shoulder supraspinatus muscle of sows fed diets containing HP was heavier ( $P$ $<.01)$ and contained more water $(P=.02)$, protein $(P<.01)$ and ash $(P<.001)$ than did the supraspinatus muscle from sows fed LP. Supraspinatus muscle fat content was greater $(P<.02)$ in sows fed HE than in those fed LE. No energy $\times$ protein interactions were observed.

In general, the carcass components were affected by dietary treatment in a manner similar to the internal organs. When dietary intake was inadequate, fat and protein were mobilized for maintenance and reproductive needs (i.e., lactation). The differences in protein in muscles indicate that sows fed diets containing LP mobilized skeletal muscle to meet lactation protein demands. Likewise, the lower fat content in most tissues of sows fed diets containing LE, compared with sows fed diets containing $\mathrm{HE}$, indicates that the sows fed LE mobilized more fat than did sows fed HE diets. The mobilization of fat was much greater in the loin soft tissue and right shoulder components than in the longissimus and supraspinatus muscles. These differences indicate that s.c. fat was mobilized at a faster rate and(or) before inter- or intra-muscular fat.

Sow Bone Properties. Energy and protein effects on sow bone properties are presented in Table 8. The results indicate that energy and protein intakes during a 28-d lactation, when equal intakes of $\mathrm{Ca}(35.5 \mathrm{~g} / \mathrm{d})$ and $\mathrm{P}(24.8 \mathrm{~g} / \mathrm{d})$ are given, had little or no effect on bone ash percentage, $\mathrm{Ca}$ or $\mathrm{P}$ percentage, bone wall thickness or metatarsal stress. The values for bone ash reported herein are similar to those reported by Mahan and Fetter (1982), who found bone ash percentages for third-parity sows fed diets containing .90\% $\mathrm{Ca}$ and $.70 \% \mathrm{P}$ to be $67.3,68.3,62.3$ and 61.2 for the humerus, femur, rib and vertebrae, respectively.

\section{General Discussion}

Results of the present experiment are consistent with previous reports (King and Williams, 1984; King and Dunkin, 1986; Brendemuhl et al., 1987) in that sows restricted in either protein or energy intake during lactation lose a considerable amount of weight, whereas backfat loss is more dependent on energy intake than on protein intake.

The composition of the weight lost by the sows during lactation was clearly diet-dependent. Sows fed LE lost more backfat and had less fat in the heart, lung, liver, viscera, loin soft tissue, right shoulder and supraspinatus muscle, indicating mobilization of fat from both intra- and inter-muscular fat depots and from internal organs. These observations are consistent with data of Shields et al. (1985), who reported that mobilization of maternal fat tissue occurs during lactation.

Sows restricted in protein intake catabolized skeletal muscle protein and organ protein to

TABLE 8. EFFECT OF ENERGY AND PROTEIN INTAKE BY PRIMIPAROUS SOWS DURING LACTATION ON COMPOSITION AND STRENGTH OF THE THIRD AND FOURTH METATARSAL BONES OF THE LEFT FOOT

\begin{tabular}{|c|c|c|c|c|c|}
\hline \multirow[b]{2}{*}{ Item } & \multicolumn{4}{|c|}{ Lactation $\operatorname{diet}^{b}$} & \multirow[b]{2}{*}{$\mathrm{CV}$} \\
\hline & LE-LP & HE-LP & LE-HP & HE-HP & \\
\hline $\begin{array}{l}\text { Bone ash }{ }^{c}, \% \\
\text { Bone Cad, } \% \\
\text { Bone } \mathrm{Pa}^{\mathrm{d}}, \% \\
\text { Wall thickness, } \mathrm{mm} \\
\text { Metatarsal stress, } \mathrm{kg} / \mathrm{cm}^{2}\end{array}$ & $\begin{array}{r}63.8 \\
37.3 \\
18.1 \\
2.5 \\
760.7\end{array}$ & $\begin{array}{r}64.5 \\
37.6 \\
18.1 \\
2.6 \\
785.6\end{array}$ & $\begin{array}{r}62.4 \\
37.9 \\
18.1 \\
2.3 \\
892.0\end{array}$ & $\begin{array}{r}63.9 \\
36.9 \\
18.0 \\
2.5 \\
751.4\end{array}$ & $\begin{array}{r}3.1 \\
4.2 \\
3.5 \\
9.4^{e} \\
22.5\end{array}$ \\
\hline
\end{tabular}

"Values are least squares means (eight sows per dietary treatment).

bLE = low energy ( $8 \mathrm{Mcal} \mathrm{ME} / \mathrm{d}) ; \mathrm{LP}=$ low protein $(380 \mathrm{~g} \mathrm{CP} / \mathrm{d}) ; \mathrm{HE}=$ high energy (16 Mcal ME/d); HP = high protein (760 g CP/d).

'Bone ash on dry fat-free basis.

${ }^{4} \mathrm{Ca}$ and $\mathrm{P}$ are percentages of bone ash.

Energy effect $(P<.10)$. 
fulfill protein demands for lactation. The supraspinatus and longissimus muscles were smaller and contained less protein in sows fed diets containing LP than in those fed HP. Heart, liver, kidney and viscera also contained less protein in sows fed LP rather than HP. These responses also are consistent with data reported by Shields et al. (1985), in which sows restricted in protein intake mobilized protein reserves to fulfill reproductive needs.

In previous experiments (Brendemuhl et al., 1987) we have shown that low protein intakes have a greater effect on the interval from weaning to first estrus than low energy intakes, and that primiparous sows fed the HE-LP diet had longer weaning to estrus intervals than sows fed the LE-HP diet. It is clear from the present experiment that although both groups of sows lose about the same amount of weight during lactation, the composition of the weight lost was quite different. Sows fed HE-LP lost primarily protein, and those fed LE-HP lost primarily fat. Considered together, the results of the present experiment and those of Brendemuhl et al. (1987) support the conclusions of King and Dunkin (1986) and King (1987) that catabolism of protein caused by a low protein intake is more deleterious to the interval from weaning to first estrus than is adipose tissue catabolism caused by a low energy intake.

\section{Literature Cited}

Allen, A. D. and J. F. Lasley. 1960. Milk production of sows. J. Anim. Sci. 19:150.

AOAC. 1980. Official Methods of Analysis (13th Ed.). Association of Official Analytical Chemists, Washington, DC.

Brendemuhl, J. H., A. J. Lewis and E. R. Peo, Jr. 1987. Effect of protein and energy intake by primiparous sows during lactation on sow and litter performance and sow serum thyroxine and urea concentrations. J. Anim. Sci. 64:1060.

Crenshaw, T. D., E. R. Peo, Jr., A. J. Lewis and B. D. Moser. 1981. Bone strength as a trait for assessing mineralization in swine: A critical review of techniques involved. J. Anim. Sci. 53:827.

Duee, P. H. and B. Desmoulin. 1982. Changes in the body composition of nulliparous sows during the reproductive cycle: Effect of the dietary protein level during gestation. p 11, 14th French Swine Research Days. Institut National de la Recherche Agronomique, L'Hermitage, France.
Elsley, F.W.H., R. M. MacPherson and G. A. Lodge. 1968. The effects of level of feeding of sows during pregnancy. III. Body composition. Anim. Prod. 10: 149.

Frankel, S., S. Reitman and A. C. Sonnenwirth (Ed.). 1970. Gradwohl's Clinical Laboratory Methods and Diagnosis (7th Ed.). The C. V. Mosby Co., St. Louis, MO.

King, R. H. 1987. Nutritional anoestrus in young sows. Pig News Info. 8:15.

King, R. H. and A. C. Dunkin. 1986. The effect of nutrition on the reproductive performance of first-litter sows. 4. The relative effects of energy and protein intakes during lactation on the performance of sows and their piglets. Anim. Prod. 43:319.

King, R. H. and I. H. Williams. 1984. The effect of nutrition on the reproductive performance of first-litter sows. 2 . Protein and energy intakes during lactation. Anim. Prod. 38:249.

Lu, K. H., L. M. Winters, W. J. Aunan and W. E. Rempel. 1958. Estimating the percentage of lean and fat in swine carcasses. Minnesota Agric. Exp. Sta. Tech. Bull. 224.

Mahan, D. C. and A. W. Fetter. 1982. Dietary calcium and phosphorus levels for reproducing sows. J. Anim. Sci. 54:285.

NPPC. 1983. Procedures to Evaluate Market Hog Performance (2nd Ed.). National Pork Producers Council, Des Moines, IA.

NRC. 1979. Nutrient Requirements of Swine (8th Ed.). National Academy Press, Washington, DC.

O'Grady, J. F., F.W.H. Elsley, R. M. MacPherson and I. McDonald. 1975. The response of lactating sows and their litters to different dietary energy allowances. 2. Weight changes and carcass composition of sows. Anim. Prod. 20:257.

Reese, D. E., B. D. Moser, E. R. Peo, Jr., A. J. Lewis, D. R. Zimmerman, J. E. Kinder and W. W. Stroup. 1982a. Influence of energy intake during lactation on the interval from weaning to first estrus in sows. J. Anim. Sci. 55:590.

Reese, D. E., B. D. Moser, E. R. Peo, Jr., A. J. Lewis, D. R. Zimmerman, J. E. Kinder and W. W. Stroup. 1982b. Influence of energy intake during lactation on subsequent gestation, lactation and postweaning performance of sows. J. Anim. Sci. 55:867.

Reese, D. E., E. R. Peo, Jr. and A. J. Lewis. 1984. Relationship of lactation energy intake and occurrence of postweaning estrus to body and backfat composition in sows. J. Anim. Sci. 58:1236.

SAS. 1979. SAS User's Guide: Statistics. SAS Inst., Inc., Cary, NC.

Shields, R. G., Jr., D. C. Mahan and P. F. Maxson. 1985. Effect of dietary gestation and lactation protein levels on reproductive performance and body composition of first-litter female swine. J. Anim. Sci. 60:179.

Steel, R.G.D. and J. H. Torrie. 1980. Principles and Procedures of Statistics: A Biometrical Approach. (2nd Ed.). McGraw-Hill Book Co., New York.

Whittemore, C. T., M. F. Franklin and B. S. Pearce. 1980. Fat changes in breeding sows. Anim. Prod. 31:183. 